\title{
English Training for Mangrove Preservation Employees as a Community Service
}

\author{
Samuel Gunawan
}

\author{
Department of English, Petra Christian University, Surabaya, Indonesia \\ Email: samgun@petra.ac.id
}

\begin{abstract}
This case study investigated a community service in the form of an English training done by the writer's colleagues. This English training was to upgrade the speaking competence of a group of employees of a cooperation unit working on mangrove preservation. The approach of the English training was eclectic, making good use of some methodological and technical options from some different approaches in English language teaching which were best suited to the specific needs of the client learners. Ample opportunities were given to them to participate, both individually and collaboratively, in the construction of the instructional materials. Pictures were used to bring the learners' real world into the classroom. The procedures of the whole program followed the sequence: needs analysis, designation of the topics, practices from sentence building to text building, and immersion in the learners' customized lessons. Pattern practices, formulaic forms, meaning-based translation were also used to enhance the client learners' speaking competence; thus, creating their greater confidence to express themselves in English.
\end{abstract}

Keywords- Community service, English training, practical English training, Community empowerment.

\section{INTRODUCTION}

In addition to two other academic duties - teaching and doing a research - every faculty member in tertiary education in Indonesia is required to get involved in practical community services as part of the three pillars of education in Indonesia (cf. Undang-Undang Republik Indonesia, n.d.). This community service activity is deemed to become university's medium of transferring some knowledge or skills from science, technology and arts/humanities to help upgrade the quality of the social life and welfare of a designated target community. Related to the case study of an English Training (henceforth referred to as ET) undertaken in this research, some previous community services done in the nonformal context of education could be exemplified in the forms of English training intended to upgrade the English skills of the members of target communities related to tourism economy (Rajeg et al, 2006; Sudipa et al, 2010,
Widodo \& Hastuti, 2011), environment protection (Martiana, Mardhiyaningsih \& Nebula, 2011), and character development (Gunawan, Djundjung \& Meilinda, 2013) Mostly these ETs applied the methods such as introducing sentence structures and provided drills to enforce the mastery of English skills, except the last one which taught children to master children songs containing values for character building. This kind of social service could probably be very unique as it is found only in Indonesian context.

Unlike in formal schools, developing instructional materials and implementing them in non-formal instructional activities for a short span of time intended for learners of mixed backgrounds constitutes a quite challenging job. It, therefore, needs an in-depth exploration of the English Language Teaching (ELT) tenets to seek appropriate methodological and technical options to be applied to meet such a challenging demand. This case study investigated the teaching and learning processes of English as a community service for the mangrove preservation employees. These target learners were employed by Griya Karya Tiara Kusuma - a medium-scale cooperation unit working on non-profit activities related to mangrove preservation in the eastern coast of Surabaya, Indonesia. Totally, there were eighteen adult learners. Despite their different levels of the English competence, they were all assigned by their superior to join the same instructional activities to help them upgrade their competence to express themselves in English related to their occupation. The knowledge gained from the best practices being investigated is expected to open our minds as to the kinds of methodological and technical options for a short ET well-suited to the specific needs of the target learners. The teaching and learning processes of the ET in this article was represented by the samples of the instructional activities of lesson 1 and lesson 2 (week 2 and week 4 out of the fourteen weekly sessions).

\section{LITERATURE REVIEW}

The kind of the ET undertaken in this study was carried out in the non-formal context of education. Like other activities in non-formal education, the ET as a social 
service activity is recognized to be beneficial to upgrade occupational competencies and further community development (Hiemstra, 2003 cited in Ololube \& Egbezor, (n.d.).

Long (2005, pp. 1, 2; cf. also Nunan, 1999, pp.148,149) stated that understanding of learner needs is a prerequisite for an effective instructional design. Therefore, prior to the implementation of a training, needs analysis (NA) has to be administered to identify the learners' needs and their levels of competence. Based on the input obtained from the NA, the appropriate approach and some relevant topics for the instructional activities of the ET need to be determined (Dirgeyasa \& Ansari, 2015, 4-24). Bearing those ideas in mind, the ET as investigated in this paper chose to employ an enlightened, eclectic approach (Brown, 2001, 39, 40), as it adopted some methodological and technical options for the instructional activities from some different approaches which were deemed to be best suited to the accomplishment of the instructional goal to meet the specific needs of the learners.

To empower the learners to express themselves in English with greater confidence, the ET used pattern practices, meaning based translation, and formulaic forms. Pattern practices were exercises on grammatical patterns which contain a word or a chunk of language paradigmatically replaceable by a list of other words or chunks of language (cf. Lado, 1958, pp. xv, xvi). Pattern practices, although might have sounded quite outdated for many language practitioners, were chosen to be implemented in the instructional activities in the ET as investigated for the reasons of their practicalities and appropriateness for the learners' specific needs and competence. Meanwhile, the principle of "meaning-based translation" (Larson, 1997, p.17) was used in cases whenever some learners wished to express some idea in English, but they could not just make it. They were assisted to express the meaning they had had related to the real world of their occupation in the source language into the natural form of the target language. Furthermore, formulaic forms - combinations of words frequently co-occurring - provided the learners with readily applicable chunks of language to be used in some situations (Ellis, 2009; Wray, 2008; Schmitt, 2006). The ET as investigated chose to incorporate the two types of formulaic forms as proposed by Hakuta (cited in Ellis, 2009, p. 71): routines and patterns. The former ones routines - were learned as memorized chunks (for example, "I don't know"); whereas the latter - patterns are partially unanalyzable chunk that has one or more open slots (for example, "May I_____?"). Following Wright (1989, pp. 2-21), to help contextualize the instructional activities, the instructor and his team used pictures in order to bring the learners' real world of their occupation into the classroom. The use of such pictures projected on the screen was very helpful to visualize meaning and create a motivating and interesting media in the instructional activities (cf. also Djahimo, 2015, pp. 65-89).

\section{METHODOLOGY}

\section{Data and research type}

The data used in this article were descriptive data in the forms of the linguistic units, the human behaviours, the participant experiences and perspectives rather than in the forms of numbers and statistics (Ary, Jacobs \& Sorensen, 2010, pp. 424, 425; Dörnyei, 2007, p. 24; Seliger and Shohamy, 1990, p. 38). The research was typically qualitative and descriptive. Being qualitative as it sought to understand the phenomena of the teaching and learning processes in the ET covering the human behaviours, the English constructions, and the human perspectives or opinions related to the ET under study (cf. Ary, Jacobs \& Sorensen, 2010, pp. 420-423; cf. Dörnyei, 2007, pp. 24, 38; Seliger \& Shohamy, 1990, pp. 38, 39); and being descriptive as it described the phenomena of the teaching and learning processes of the ET as they existed (cf. Ary, Jacobs and Razavich, 1990, p. 381; Seliger \& Shohamy, 1990, pp. 124, 125).

\section{Instructor}

The instructors consisted of four lecturers who shared the responsibility of the planning, implementation, and evaluation of the ET being investigated. Before undertaking a task in the ET, the instructors had to familiarize themselves with the occupation of the learners by browsing the issues related to mangrove preservation from the internet and familiarize themselves with the dayto-day activities of the mangrove preservation cooperation unit as they were visually represented by a collection of the cooperation unit's pictures and brochures. The writer of this article served more in drafting the planning and supervised the whole project. In this study the writer and his colleagues served as complete participants (Ary, Jacobs \& Sorensen, 2010, pp. $432,433)$ as they completely participated and became insiders in the natural activity of the ET being investigated. For evaluating the learners' progress, the instructor chose to use one of the alternative assessments in the form of a check list of the learners' behaviours focusing on their progress (cf. Huerta-Macías, 2002, pp. 339-342).

\section{Learners}

Through the NA, the researcher and his team were able to identify the learners' profiles that, from the perspective of language competence, they came from different levels of English competence; mostly at upper elementary and lower intermediate levels. Altogether, there were eighteen adult learners. From the perspective of job requirement, 
the ET was assigned to upgrade the client learners' speaking competence in order to better serve foreign visitors often coming to their workplaces. These eighteen learners were the employees of the non-governmental cooperation unit working on the mangrove preservation unit in the eastern coast of Surabaya. The cooperation unit had some related smaller-scaled production subunits such as mangrove preservation, mangrove tourism, and various mangrove-based production lines such as mangrove batik, mangrove food, beverages, medicine, and other daily necessities.

\section{Media}

In the classroom, pictures as visual representations of ideas related to the learners' real world were used covering both the topics and the learners' day-to-day activities. The former, for instance, when the instructor intended to elicit a chunk of language related to the idea of mangroves as "walking trees" or that of mangroves which grow "on the intertidal zone", he/she used such pictures which were projected from the LCD to the screen. These pictures were collected by the instructors on the planning stage of the ET. When the learners produced their own sentences, the instructor wrote them down on the laptop to be projected on the screen from the LCD so as to be visible to the learners. Such texts could be saved and used on the next stages of teaching and learning processes.

\section{Choice of Approach, Method, and Technique for the CET}

The success of a short ET as a community service depended on how well planning was made at the outset. The writer and his team explored the repertory of English Language Teaching (ELT) beliefs and their implications to the teaching of English (cf. Renandya, 2013; Ellis, 2009; Nunan, 2005), seeking some practical ELT methodological and technical options most suitable for these learners who came from different levels of English competence. Following Anthony (cited in Jack and Rodgers, 2014, p. 21), explorations were made on the notions and types of approaches, methods, and techniques. Since the goal of the ET was to improve the learners' skills to express themselves in English related to their occupation, some methodological options best suited to the specific needs of the learners were chosen from the realm of some different approaches. The focus on communication and interaction were taken from the realm of communicative language teaching (cf. Richard and Rodgers, 2014, pp. 83-107); collaborative creation of meaning from the realm of interactional approach (cf. Richard and Rodgers, 2014, p. 91); and pattern practices from audiolingual approach (cf. Richards and Rodgers, 2014, p. 58-79).
In order to meet the specific needs of the leaners to express their ideas related to their occupation, they were given ample opportunities to contribute not only the topics, but also the contents of the instructional materials. This was, for instance, obvious that in the beginning they were to share and negotiate a list of topics for the whole training. Since these adult learners were more in a position to know better of the most relevant topics related to their occupation, the instructor(s) simply helped them to decide the fixed list of topics. The use of some pictures depicting the learners' real world in the instructional activities was able to serve as non-verbal stimuli to visualize the ideas and relevant topics related to their occupation (cf. Wright, 1989, p. 18). Altogether, there were six topics. Two successive classes dealt with one topic from week 2 up to week 13. Week 1 was reserved for the NA and the pre-test; week 14 for the post-test. The instructional materials were set out to center on the following list of six topics:

1) Welcoming visitors to eastern coast of Surabaya

2) Preservation of mangrove

3) Various benefits of mangrove

4) The importance of mangrove

5) Why should we protect mangrove?

6) Mangrove for ecological tourism

\section{The Teaching and Learning Procedures}

Following Cahyono (2010), the instructional activities followed the procedures: Pre-teaching, Whilst-teaching, and Post-teaching. In addition, Reflection was added to record the instructor's comments on the instructional activities that had just been completed.

\section{- Pre-teaching}

In accordance with the designated topic, the learners were given ample opportunities, with only a little help or none at all from any of their classmates or the instructor, to express themselves in English. Tolerant of the learners' errors were shown in order to encourage them to speak English. In cases whenever some wished to express their ideas in English, but they were not able to do so, the instructor helped them express their ideas in light of "meaning-based translation" (Larson, 1997, p. 17). They were asked to translate their ideas from the source language into the natural form of the target language. This was to minimize their errors. Eventually, some focused sentences produced by the learners were chosen and used as sentence patterns, from which they were to build more and more new sentences, incorporating some necessary substitutions. They were encouraged and motivated to express themselves using those patterns to be further strengthened by the use of relevant formulaic forms. By so doing, more and more English sentences coming from the learners' own stock of knowledge were produced and practised. 
- Whilst-teaching

The specific strategy of the writer's team was to work together with the client learners-the so-called collaborative creation of meaning-to build a text for the customised instructional materials well-suited to their specific needs. On this stage, the learners were to work collaboratively to draft a self-contained text using previous focused sentences. Finally, the instructor and the whole class worked together to refine the draft to become a finished version of a well-organised text that could be appropriately used as the instructional material to be mastered by the learners.

- Post-teaching

On this stage, the learners were expected to be able to speak more confidently in their role play. The instructional materials were basically the ones they had previously produced on the previous stage of sentence building up to that of text building. The instructor applied the principle of "read, then say it" when the learners were expected to express their parts in the role play. They were only allowed to read their parts before saying them, just to make sure that they got them right. When they expressed them, they were not allowed to read them. They were to do their best to rely on their memory. In this way, the relevant sentence patterns were instilled and reinforced to become part of their working knowledge and skills. On this stage of learning, they were expected to express themselves in English more fluently and naturally. Thus, on this stage, the instructor were enabled to evaluate each learner's progress. The instructor used an alternative kind of assessment in the form of a checklist of the learners' performance (cf. Huerta-Macías, 2002, pp. 338-343). Basically the material on this stage was based on the previous whilst-teaching stage.

- Reflection

On this stage, the instructor gave some thought of both the strengths and weaknesses of the instructional activities. He/she highlighted the strengths to be retained and the weaknesses to be addressed in the next phase of the instructional activities.

\section{Samples of the ET Sessions}

\section{Sample from Lesson 1}

- Pre-teaching

Focusing on the designated topic, welcoming visitors to eastern coast of Surabaya, all the learners were given opportunities to express themselves in English. Because they came from different levels of competence, some were able to express their ideas in good, correct English, but some others were only able to do the same thing, partly with the aid of their friends or the instructor. The point was that everybody was encouraged to take active parts in the instructional activities. Some of the sentences produced by the learners were quite relevant to the topic of the day. Therefore, some of those focused sentences were chosen to serve as the basic sentence patterns. These, in turn, could also serve well as a stock of the focused sentences for the text-building activity on the next stage later.

\section{- Sentence Building}

WELCOMING VISITORS

Instructor: (A picture was projected on the screen to show the learners' workplace with some foreign visitors) You see here, some foreign visitors were visiting your workplace. Any of you could express yourself the ideas related to this scene?

Learner 1: Good morning, madam. Good morning, sir. Welcome to Mangrove Forest Tourism Resort. Instructor: Very good. If your visitors come in the afternoon, how would you greet them?

Learners: (Together) Good afternoon.

Instructor: Very good. (To learners 2, 3, 4, and 5)

Please greet your visitors - a gentleman and a lady.

Learner 3-5: Good afternoon, madam. Good

afternoon, sir.

Learners 6-9: (Following the hand signal from the instructor) Good afternoon, madam. Good

afternoon, sir.

Instructor: Very good. What next could you say (to learners 10-18). Together, please!

Learners 10-18: (In unison) Welcome to Mangrove Forest Tourism Resort.

Instructor: Together, everybody!

Learners: (All in unison) Welcome to Mangrove Forest Tourism Resort.

Instructor: Very good. What next could you say (to some learners)

Learner 13: I want to say this, sir: atas nama manajemen, I welcome you to Pamurbaya.

Instructor: Anybody knows? Good, you, please say it!

Learner 18: On behalf of the management, I welcome you all to Pamurbaya.

Instructor: What is Pamurbaya? Pamurbaya is short for

Learners: (Some in unison) Pamurbaya is short for

Pantai Timur Surabaya.

Instructor: How do you say Pantai Timur Surabaya in English?

Learner 16, 17: Eastern coast of Surabaya. Instructor: Very good. Repeat together after me! Pamurbaya is short for Pantai Timur Surabayaeastern coast of Surabaya.

All learners: (All in unison) Pamurbaya is short for Pantai Timur Surabaya - eastern coast of Surabaya. Instructor: Introduce yourself and say it that you are their guide. 
Learner 10: My name is Sutini. Call me Tini. I am your guide.

Instructor: (After giving opportunities to some learners to introduce themselves) Well, now it's time to proceed to the next step.

\section{- Whilst-teaching}

On this stage, the learners were asked to recall some focused sentences to build a conversation. The instructor wrote the different parts of the dialoques on the laptop and they were projected from the LCD on the screen to further encourage the learners' collaborative work to finish the dialogue to their satisfaction. As soon the dialoque was finished, the instructor erased some words from the sentences. Then the learners were asked to practise the role play in a small group. They were to supply necess ary, relevant chunks to the given slots in the patterns. The instructor encouraged the learners to change the role they were playing until everybody got all the different roles. In this way, all of them had the opportunity to practice the entire role play. Meanwhile, other instructors who were present also assisted the learners to express their ideas as naturally as possible, using proper English rhythm, intonation, and pronunciation.

\begin{tabular}{|c|}
\hline $\begin{array}{l}\text { Role Play } \\
\text { WELCOMING VISITORS (in a small group of three) } \\
\text { Guide: Good } \\
\text { Visitor 1: Good, } \\
\text { Visitor 2: Good, } \\
\text { Guide: Welcome } \\
\text { My _-__ }\end{array}$ \\
\hline
\end{tabular}

Then, all the learners were invited to take active parts in the text-building processes by putting together their previous focused sentences to make up a self-contained text. As usual the instructor wrote down their contribution on the laptop, whose image was projected from the LCD on the screen. The learners were continually encouraged to contribute more ideas until the text really satisfied their needs. After that, the exercises on reading and listening were done based on the completed text. The point here was to integrate the different skills of language as found in the real life. Whenever necessary, this text could also be modified to serve as a basis for writing exercise.
Text Building

\section{WELCOME TO EASTERN COAST OF SURABAYA}

Good morning, sir. Good morning, madam. Here you are on the eastern coast of Surabaya. It's nice to see you all. On behalf of the management, I welcome you to Pamurbaya. Pamurbaya is short for Pantai Timur Surabaya - eastern coast of Surabaya. This is a mangrove forest tourism resort.

My Name is Pertiwi. You may call me Wiwiek.

I am your guide to see around the mangrove forest touris $m$ resort.

I hope you'll have a good time to see around the mangrove forest.

- Post-teaching

The instructor applied the principle of "read, then say it" when the learners had to play their roles. They were only allowed to read their parts before saying them, just to make sure that they got them right. When they had to express them, they were not allowed to read them from the projected text on the screen. They were to do their best to rely on their memory. In this way, the relevant sentence patterns were instilled and reinforced to become part of their working knowledge and skills. On this stage of learning, they were expected to express themselves more fluently and naturally. Thus, on this stage, the instructor simultaneously were enabled to evaluate each learner's progress. Basically, the instructional material was taken from the previous whilst-teaching stage.

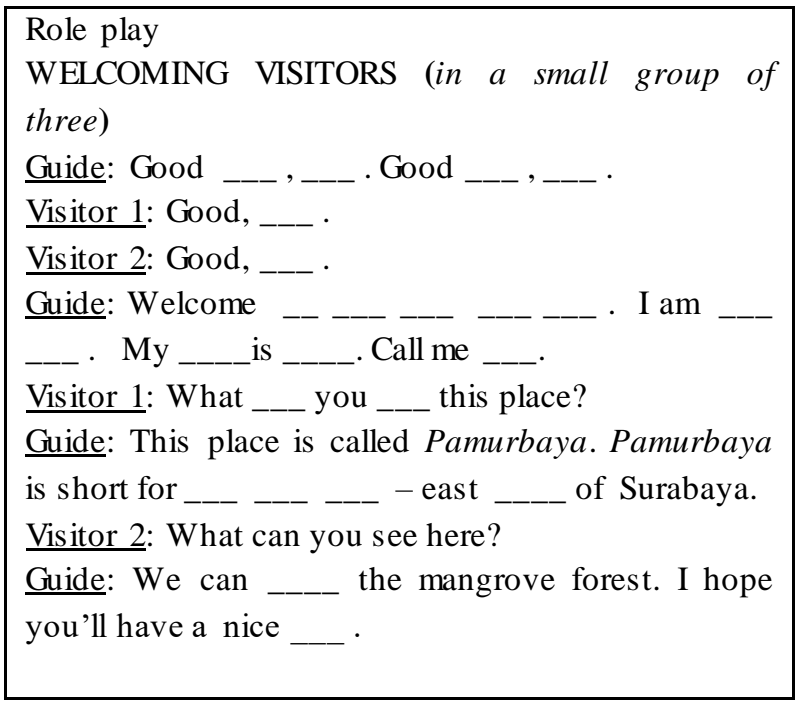

On a small group of two or three people, the learners took turns practicing reading the text by filling in the blank slots. Most of them were able to do this very well since the ideas originally came from them. In other words, they were very familiar with the text as they had participated from the stage of sentence building up to that of text building. 


\section{- Reflection}

The goal of upgrading the client learners' speaking competence was obviously within the ET's reach as the client learners participated enthusiastically in the individual as well as collaborative work to build and practise the focused sentences and the self-contained text from their own stock of knowledge and skills. The pictures showing the learners' workplaces helped them focus on expressing the ideas related to their occupation. In this way, the instructional materials were tailor-made to meet their needs to express themselves in English related to their occupation within the confine of the designated topics. The instructor's continual encouragements were important as they created more conducive atmosphere for the learners' active roles. Ample opportunities were given to the weak learners to catch up with the class progress. The other instructors who were present could assist any of them on an individual basis.

\section{Sample from Lesson 2}

Focusing on the designated topic of lesson two - the functions and benefits of mangroves, the learners were encouraged to express their ideas in English. As having been done previously, some were able to express their ideas in good, correct English, but some others, only partly with the aid from their colleagues or the instructor, were able to do so. Some of their focused sentences could make up as the basic sentence patterns related to the topic of the day. These could also serve as a stock of the focused sentences for the text-building processes later.

- Pre-teaching

Instructor: (Showing a text with some blank spaces on the screen, then asking a pair of the learners to do a role play). Imagine it's in the morning in your workplace. Anybody could start our class today by completing the following dialogue?

Guide : Good

Tourist: Good

Guide : I 'm

Tourist: O.K.,

Guide : I welcome you to

Instructor: (To the two learners who were raising their hands) O.K., please say it !

Learner15 \&16:

\section{Guide: Good morning.}

Tourist: Good morning.

Guide: I 'm your guide. My name is Mimi.

Tourist: O.K., thanks.

Guide: I welcome you to the Mangrove Forest Tourism Resort.

Instructor: Fine. All of you, repeat once again!
All learners: (Repeating the whole patterns, following the instructor's hand signal)

Instructor: (Showing a projected picture on the screen of mangroves which grow on the intertidal zone) This area is called intertidal zone - the intertidal zone. Complete the following: Mangroves grow on _-_________-_. (the intertidal zone)

Learners 2-5: (Together) Mangroves grow on the intertidal zone.

Instructor: (Asking learners in a group of four or five to repeat it until everybody got the turn. Finally, all the learners were asked to repeat) O.K., repeat it once again! All learners: Mangroves grow on the intertidal zone.

Instructor: (Showing the next picture of mangroves. Their roots are above the water) Could you say anything about this!

Learners: (With a little help from the instructor) The roots of mangroves are above the water.

Instructor: Very good. (Then, showing a picture that the mangroves look like "walking trees") Look at this picture. Could anybody say anything about this?

Learner 15: Mangroves look like walking trees.

Instructor: Fine. Mangroves look like walking trees. So, people often called them ?

Some learners: walking trees.

Instructor: Please repeat once again from the beginning: Mangroves grow _-_____________. The roots of mangroves _________________. Because they look like , people often call them

Learners: (In a group offour or five, they were to repeat the whole sentence patterns until every group got their turns). Mangroves grow on the intertidal zone. The roots of mangroves look like walking trees. Because they look like walking trees, people often call them walking trees. Instructor: O.K., let's move on.

- Whilst-teaching

The learners were asked to express themselves in a group of four by completing the given blank spaces of the text projected on the screen, starting from the patterns they had just learned to proceed to the new items. At the same time, they would have to learn new words by translating the given words from Indonesian into English. In this way, the learners were not only expected to learn the focused sentence patterns, but also increase their vocabulary related to their occupation.

Role play
The Different Functions of Mangroves
Guide: Good
Tourist 1,2: Good _-_.
Guide: I 'm
Tourist 2: O.K. , -_- .
Guide: I welcome you to the Mangrove Forest
Tourism Resort. Mangroves grow in the intertidal


zones. You can see that the roots are above the water. They look like walking trees. That is why people often called them "walking trees".

Tourist 1: Why is it important to conserve the mangrove forest?

Guide: Because they provide (makanan), (tempat berteduh) and

(daerah perkembang-biakan) for fish, birds, and other marine lives. (= food, shelter, nursery

areas). They also prevent (banjir) and (erosi). (= flood, erosion). The roots (menyaring) the water and (mencegah)

erosion.(= filter, prevent)

Tourist 2: Why can mangroves survive in the harsh conditions?

Guide: Because their roots can filter salt water, and their leaves can excrete salt.

Tourist 2: I see.

The learners were asked to participate in the text-building processes by contributing relevant sentences of their own expressing the ideas related to the designated topic of the day. The instructor put together their contribution on the laptop, whose image was projected on the screen, so as to be visible to every learner. The instructor only served the role to assist the learners to express/communicate their ideas to make up a self-contained text that satisfied their needs. Having completed the text, the learners in a group of two or four people were asked to take turns practising reading and listening. These were repeated a couple of times until every body played all the different roles. They were encouraged to act out their parts as naturally as possible. Whenever necessary, this text could also serve as an exercise for writing later.

○ Text Building

\section{The Benefits of Mangroves}

Tourist 1: Is it right that mangroves are very useful for food, beverages, and cosmetics?

Guide 1: You are right. They have a lot of functions: for food, beverages, cosmetics and medicines. For food, from the fruit of mangroves, you can produce syrup. You can also process mangrove to produce snacks, candy, crisps, or crackers. The crackers are made of flour, mangrove, and fresh-water black fish. After you fry them, the fried crackers will be crispy. They taste delicious. The waste can still be benefitted to produce natural liquid soap.

Guide 2: For cosmetics, you can produce face powder, hand and body lotion, body scrub, astringent, shampoo, conditioner, soap, et cetera. The sap from mangroves can also cure open wounds and

\section{sores.}

Guide 1: You can also produce mangrove batik. The batiks may have various mangroves motifs depicting different parts of mangrove: leaves, flowers, fruits, a bunch of fruits, and various marine lives such as fish, shrimp, crab, and oyster.

Tourist 2: Wow! You are really very good. Thank you for your explanation.

Guide: You're welcome.

\section{- Post-teaching}

All the learners had to play their roles in a small group of three or four people. They had to take turns playing the different roles. The instructor reminded them to apply the principle of "read, then say it" from the projected text on the screen when they were expected to play their roles. They were only allowed to read their parts before saying them, just to make sure that they got them right. When they were expressing them, they were not allowed to read them. They were encouraged to do their best to rely on their memory. In this way, the relevant sentence patterns were instilled and reinforced to become part of their working knowledge. From the observation, most of them could do their parts very well, because the text were obtained from their collaborative contribution. In other words, what the learners did were mostly the attempts to express in the new ways of the expressions of the contents/ideas that they had had at their disposal. On this stage of learning, they were expected to express themselves more fluently and naturally. Thus, on this stage, the instructor were simultaneously enabled to evaluate each learner's progress. Basically the instructional material was taken from the previous whilstteaching stage.

- Role play

\section{The Different Functions of Mangroves}

Guide: Good

Tourist 1,2: Good

Guide: I' $\mathrm{m} \ldots \ldots$ _._. My name is

Tourist 2: O.K., _-_.

Guide: I welcome you to the Mangrove Forest Tourism Resort. Mangroves grow in the intertidal zones. You can see that the roots are above the water. That is why people often called them "walking trees".

Tourist 1: Why is it important to conserve the mangroves forest?

Guide: Because they provide (makanan), (tempat berteduh) and

(daerah perkembang-biakan) for fish, birds, and 
other marine lives. They also prevent

(banjir) and (erosi). The roots

(menyaring) the water and (mencegah) erosion.

Tourist 1: Why can mangroves survive in the harsh conditions?

Guide: Because their roots can salt water, and their leaves can salt.

Tourist 1: I see.

\section{The Benefits of Mangroves}

Tourist 1: Is it right that mangroves are very

for food, beverages, and cosmetics.

Guide 1: You are right. They have a lot of functions:

for food, and For

food, from the fruit of mangroves, You can syrup. You can also process mangroves to produce , and , or The crackers are made of flour, mangrove, and fresh-water black fish.

After you fry it, the fried crackers will be . It

tastes The waste can still be to produce natural liquid soap.

Guide 2: For cosmetics, you can have hand and body lotion, astringent, shampoo, conditioner, soap, et cetera. The from mangroves can also open wounds and sores. Guide 1: You can also produce mangrove batik. The batiks may have various mangrove motifs different parts of mangroves: leaves, flowers, fruits, a bunch of fruits, and various lives such as

fish, shrimp, crab, and oyster.

Tourist 2: Wow! You are really very good. Thank you for your explanation.

Guide: You're

- Reflection

Bearing in mind of the previous stages of the teaching and learning processes, a reflection could be made:

a) The goal of empowering the learners to have greater confidence to communicate the ideas related to their occupation was within their reach as the client learners were encouraged to participate in the collaborative work to build the focused sentences and the self-contained text from their own stock of knowledge and skills. In that way, the instructional materials were tailor-made to meet their needs to express themselves in English related to their occupation within the confine of the designated topic. Toward that goal, the learners were invited and encouraged, partly with the help of their own colleagues or the instructor if necessary, to express in English of the ideas related to the designated topic of the lesson. Even, this did not matter at all if some learners, at first, had their ideas only in the source language, Indonesian. If this happened, they would be asked to stick to the ideas in the source language and then, partly with the assistance of their colleagues or the instructor, they would be asked to do their best to express them in the appropriate form of the target language.

b) Focused sentences related to the occupation and the topic of the lesson were mostly obtained from the learners' stock of knowledge. They made up relevant structural units for the expression of the learners' ideas. Through a process of text building, all of these could be collected to make up a self-contained reading text on the designated topic. Based on the entire English sentences that the learners had produced in the class, the instructor negotiated with the learners in arranging and systematizing the focused sentences to become a selfcontained text. In short, the instructional materials came from the learners themselves, and the instructional material, having been reorganized and systematized, eventually went back to their own use.

c) The conducive atmosphere created in the class was quite supportive to the learners to have greater confidence in speaking English as seen from:

$\circ$ the learners' individual and collaborative creation of their own course materials.

o the learners' active involvement in the instructional activities.

o the instructor's continual encouragements and explorations to bring the learners' potentials as well as their real world outside the class room to existence in the instructional activities.

\section{CONCLUSIONS AND PEDAGOGICAL IMPLICATIONS}

The article has shown the teaching and learning processes of the ET that the writer and his team had the opportunity to implement in their community service. From the ET that was investigated, some good practices can be learned such as:

a) Needs analysis should be administered in advance for an effective training.

b) The best approach, method, and techniques are the ones most appropriate to the needs and competence of the target learners to accomplish the goal of the instructional activities.

c) Following the eclectic approach, the instructor and his team chose methodological and technical options best suited to the needs and competence of the target learners.

d) Prior to the teaching and learning processes, the instructor had to be well-equipped with the register related to the learners' occupation. 
e) By applying the principle of sentence building to text building and that of "read, then say it" as practised in the ET as investigated, the learners were encouraged to express their ideas related to their occupation. In this way, they were empowered a great deal to express better of the ideas related to their work.

f) The use of patterns practices, formulaic forms, meaning-based translation, and pictures related to the learners' occupation provided them with useful grammatical forms, vocabulary, and chunks of speech readily applicable for the new ways of expressing the ideas related to their work. They were potentials for extending the learners' mastery of their specific English related to their occupation.

This empirical article hopefully can open our minds as to the kinds of the methodological and technical options for an effective teaching and learning in a community service taking the form of an ET to cater for the specific needs and competence of the target learners of different levels of competence.

\section{ACKNOWLEDGEMENTS}

I wish to thank to the following:

* My colleagues for a fruitful discussion of the community work as investigated in this article.

** My debriefer, for her candid and constructive comment on the earlier draft of this article.

\section{REFERENCES}

[1] Ary, D., Jacobs, L.C. \& Razavich, A. (1990). Introduction to research in education (4 $4^{\text {th }}$ ed.). Forthworth: Harcourt.

[2] Ary, D., Jacobs, L.C. \& Sorensen, C. (2010). Introduction to research in education ( $8^{\text {th }}$ ed.). Belmont: Wadsworth Cengage Learning.

[3] Brown, H. D. (2001). Teaching by principles: An interactive approach to language pedagogy $\left(2^{\text {nd }}\right.$ ed.). NY: Pearson Education.

[4] Cahyono, B.Y. (Ed.). (2010). Teaching English by using internet resources. Malang: State University of Malang Press.

[5] Dirgeyasa, I.W. \& Ansari, K. (2015).The study of needs analysis of tourism topics and English linguistics features through local-based needs at the golden triangle tourism destination in North Sumatra Province Indonesia. Asian EFL Journal, Issue 86, 424.

[6] Djahimo, S. (2015) The attitudes of teachers and students of EFL classes toward English teaching and learning using games and pictures in rural and disadvantaged schools in Indonesia: A case study. Asian EFL Journal, Issue 86, 65-89.
[7] Dörnyei, Z. (2007). Research method in applied linguistics. Oxford: Oxford University Press.

[8] Ellis, R. (2009). The study of second language acquisition ( $2^{\text {nd }}$ ed.). Oxford: Oxford University Press.

[9] Gunawan, S., Djundjung, J.M. and Meilinda. (2013). Bermain dan belajar Bahasa Inggris berbasis pendidikan karakter. In Share: Journal of service learning, Vol. Number 1, 36-43.

[10] Huerta-Macías,A.(2002). Alternative assessment:

[11] Responses to commonly asked questions. In J.C. Ricards \& W.A. Renandya, Metodology in language teaching: An anthology of current practice (pp. 338343). Cambridge: Cambridge University Press.

[12] Lado, R. (1958). English pattern practices. Ann Arbor: The University of Michigan Press.

[13] Larson, M.L. (1997). Meaning-based translation: A guide to cross-language equivalence. Lanham: University Press of America.

[14] Long, M. H. (2005). Overview: A rationale for needs analysis and needs analysis research. In M. H. Long (ed.), Second language needs analysis. Cambridge: Cambridge University Press.

[15] Martiana, N., Mardhiyaningsih, I., \& Nebula, D.(2011). Pelatihan Keterampilan Bahasa Inggris bagi Komunitas Prenjak sebagai Upaya Mewujudkan magrove Education Center (MEC). Retrieved from http://lp2m.unnes.ac.id/file/Abstrak\%20PM\%20201 1/Abstrak\%20Pengabdian\%202011_webmetrics_ 128.pdf

[16] Nunan, D. (1999). Second language teaching and learning. Boston: Heinle \& Heinle Publishers.

[17] Ololube, N.P. \& Egbezor, D.E. (n.d.). A Critical Assessment of the Role/Importance of Non-Formal Education to Human and National Development in Nigeria: Future Trends. International Journal of Scientific Research in Education, June 2012, Vol.5(2), 7193. Retrieved from http://www.jisre.com/Vol., 5_2_-Ololube \& Egbezor.pdf

[18] Rajeg, I.M et al. (2006). Pengenalan Etika Berbahasa Inggris Kelompok Sadar Wisata di Desa Bongkasa, Kabupaten Badung. Retrieved from http://ojs.unud. ac.id/index.php jum/article/view/1834

[19] Renandya, W. (2013). Current beliefs in ELT and their implication for language teaching. Proceeding English Education - UNS International TEFL Conference.

[20] Richards, J.C. \& Rodgers, T.S. (2014). Approaches and methods in language teaching ( ${ }^{\text {rd }}$ ed.). Cambridge: Cambridge University Press. 
[21] Richards, J. C. \& Renadya, W.A. (Eds.). (2005). Methodology in language teaching: An anthology of current practice. Cambridge: Cambridge University Press.

[22] Schmitt, N. (2006). Formulaic language: fixed and varied.

[23] Estudios de lingüística Inglesa aplicada, 6, 13-39.

[24] Seliger, H.W. \& Shohamy, E. (1990). Second language research methods. Oxford: Oxford University Press.

[25] Sudipa, I.N. et al. (2010). Pelatihan Bahasa Inggris komunikatif bagi kelompok Sadar Wisata di desa Carang Sari Badung Utara. Udayana Mengabdi, Volume 9 Nomor 2 Tahun 2010.

[26] Undang-undang Republik Indonesia nomor 20 tahun 2003 tentang Sistem Pendidikan Nasional. (n.d.).Retrieved from http://kemenag.go.id/file/ dokumen/UU2003.pdf

[27] Widodo, Y. \& Hastuti, E.d. .(2011). English conversation bagi pedagang souvenir. Retrieved from http://lppmbantara.com/pros_01222227.pdf

[28] Wray, A. (2008). Formulaic Language: Pushing the boundaries. Oxford: Oxford University Press.

[29] Wright, Andrew. (1989). Pictures for language learning. Cambridge: Cambridge University Press. 